\title{
SEROTYPING AND IDENTIFICATION OF CAMPYLOBACTER JEJUNI AND CAMPYLOBACTER COLI STRAINS OF HUMAN AND ANIMAL ORIGIN USING THE PCR METHOD
}

\author{
I. STEINHAUSEROVÁ, K. FOJTÍKOVÁ \\ Department of Meat Science, Faculty of Veterinary Hygiene and Ecology, \\ University of Veterinary and Pharmaceutical Sciences, Brno, Czech Republic \\ Received August 26, 1998 \\ Accepted March 31, 1999
}

Abstract

Steinhauserová I., K. Fojtíková: Serotyping and Identification of Campylobacter jejuni and Campylobacter coli Strains of Human and Animal Origin Using the PCR Method. Acta Vet. Brno 1999, 68: 149-154.

A total number of 178 strains of Campylobacter spp. from human patients suffering from diarrhea and from the intestinal content of slaughtered pigs and poultry was isolated during years 1996 to 1997. Campylobacter strains were isolated and identified by standard tests and the PCR method using fla A and fla B, as well. Isolates originating from human patients were identified as Campylobacter jejuni $(98 \%=108$ strains) and C. coli $(2 \%=2$ strains). Campylobacter $\mathrm{spp}$. (20) strains obtained from slaughtered pigs were identified using standard tests in $45 \%$ (9 strains) and $40 \%$ (8 strains) as C. coli and C. jejuni, respectively. Strains of Campylobacter spp. (48) isolated from slaughtered poultry were identified as $C$. jejuni $(89 \%=42$ strains $)$. Standard tests failed to identify 9 strains; 6 strains were identified as Campylobacter jejuni and $C$. coli using the PCR method. Serotyping using 34 antisera of the Penner's serotyping scheme was performed in 130 strains of Campylobacter jejuni isolated from poultry and human patients. This method was suitable for identification of almost $80 \%$ of $C$. jejuni strains. We found 10 different serotypes of human C. jejuni strains. There were serotypes (HS) 4, 1 and 9 (32\%, $23 \%$ and 15\%, respectively) predominating in the human population; they were followed by serotypes (HS) 10, 2 and 23 (8\%, $5 \%$ and $3 \%$, respectively). Animal strains included 7 (HS) serotypes. Like in the human strains, the serotype 4 , found in $37 \%$ of examined isolates, was predominating. Serotypes 23 and 1 (17\% and $15 \%$, respectively) were the next most frequent ones. Comparing the obtained serotypes of human and animal strains we see that there are only 4 identical ones (i.e., 4, 1, 10, 23), which are, however, most frequently occurring in both groups of strains.

The PCR methods and serotyping may facilitate and make more accurate the results of standard cultivation and in epidemiologically serious cases help in explaining the route of transmission.

Campylobacter jejuni/coli, PCR, HS antigen, food-borne diseases

Diseases caused by Campylobacter spp. belong to the most prevalent infections in many countries. From all the known Campylobacter species, diseases are caused most frequently by Campylobacter jejuni and to a lesser extent by Campylobacter coli. Diseases caused by other species, such as $C$. upsaliensis and $C$. hyointestinalis, have been, however, described (S aleha et al. 1998). Campylobacter spp. are very common in domestic and wild animals from which they are rather often and easily isolated. On the other hand, isolations of Campylobacter spp. from risk foodstuffs succeed with difficulty. There may be many causes for this. One of them is the low number of Campylobacter spp. cells which are not detected by standard methods. Another reason is the high sensitivity of Campylobacter spp. to the external environmental factors (such as $\mathrm{pH}$, humidity, $\mathrm{NaCl}$, presence of oxygen and others) leading to the damage of cells (Steinhau serová 1998). The existence of viable but nonculturable cells not only of Campylobacter spp. but also of other microorganisms has been proven recently. These forms of microorganisms cannot be found using standard methods but it is probable that they may cause the disease (McDougald et al. 1998).

Address for correspondence:

Doc. MVDr. Iva Steinhauserová, CSc.

University of Veterinary and Pharmaceuticcal Sciences

Dept. of Meat Hygiene and Technology
Phone: +4205 41562660

Fax: + 420541321230

http://www.vfu.cz/acta-vet/actavet.htm 
Transmission of Campylobacter jejuni to humans may take the route of direct contact with animals or a sick person but most frequently indirectly by consuming contaminated food and water (Stein hau serová 1998). With the increasing number of campylobacter enteritis there are growing efforts to explain routes of Campylobacter jejuni/coli transmission. Means and routes of Campylobacter spp. transmission have not been fully clarified yet. Serotyping is one of possibilities to identify and evaluate the epidemiological relation of strains isolated from different sources and patients. Numerous methods using different surface structures such as polysaccharides, lipopolysaccharides or proteins have been described in the past. Two systems began to predominate in the course of time. One of them is based on the use of thermostable polysaccharides (the Penner's serotyping scheme) and the other on the identification of thermolabile flagellar proteins (the Lior's scheme). The use of serotyping methods is limited, and, therefore, methods of genotyping have been employed more and more recently. It is possible to combine phenotypic methods and genotypic identification using molecular methods which may reliably identify strains isolated from animals and human patients, their characteristics and probable routes of transmission (A arts et al. 1995; Madden et al. 1998).

There is no laboratory engaged in routine serotyping of Campylobacter jejuni and Campylobacter coli in the Czech Republic, so the frequency of occurrence of individual serotypes is not known.

It is the aim of our work to perform serotyping and identification by the PCR method using the collection of isolated strains of human and animal origin.

\section{Materials and Methods}

Isolation of Campylobacter spp. strains

Campylobacter strains from human patients and animals were collected during the years 1996 to 1997. Human strains were obtained owing to the cooperation with the laboratory of microbiology Bioplus and originated from rectal swabs from the south Moravian region patients suffering from gastrointestinal diseases. Animal strains were obtained by sampling the intestinal content of the large intestine and caecum of pigs and poultry immediately after slaughter. Strains from poultry were isolated from slaughtered animals from 5 different Moravian herds; the slaughtered pigs originated from the whole south-Moravian region. The isolation and identification of Campylobacter jejuni/coli was performed using the modified ČSN ISO Norm 10272 "The microbiology of food and foodstuffs - the horizontal method of identification of thermotolerant species of the genus Campylobacter."

After taking of about $1 \mathrm{~g}$ of the intestinal content, the sample was directly plated on a solid selective medium (Campylobacter Agar Base (Karmali) Oxoid) and simultaneously enrichment in $10 \mathrm{ml}$ of the Preston broth. The solid culture media were incubated at $37^{\circ} \mathrm{C}$ for $48 \mathrm{~h}$. The propagation lasted for 16 to $18 \mathrm{~h}$ under microaerophiolus conditions at $42{ }^{\circ} \mathrm{C}$. For the purpose of achieving microaerophilous conditions we used the Campylobacter Gas Generating Kit (Oxoid). Propagated samples were plated on the Blood Free Campylobacter Selective Agar Base (Oxoid) and Campylobacter Agar Base (Karmali) Oxoid and cultivated at 37 or $42{ }^{\circ} \mathrm{C}$ under microaerophilous conditions.

Suspect colonies were re-plated on the Blood Agar Base No. 2 (Oxoid) with the aim to obtain pure Campylobacter cultures. Standard biochemical examinations were performed according to the recommendation of the CSN ISO Norm (i.e., catalase, oxidase, hippurate hydrolysis, hydrogen sulphide production in TSI, growth at $37^{\circ} \mathrm{C}$ (aerobically, anaerobically and microaerobically), $30^{\circ} \mathrm{C}$ aerobically, $43{ }^{\circ} \mathrm{C}$ microaerobically; susceptibility to discs containing cephalothin $(30 \mu \mathrm{g})$ and nalidixic acid $(30 \mu \mathrm{g})$. Isolated strains were kept at $-60^{\circ} \mathrm{C}$ in the Meat Cooked Broth (Oxoid).

\section{Serotyping}

Selected strains were serotyped using the Penner's serotyping scheme described by Penner and Hennessy (1980). For the purpose of typing the strains using the thermostable (HS) lipopolysaccharide antigens, the method of passive hemagglutination by commercial sera (PHL Manchester) was employed. Serotyping was performed using 34 antisera: $1,2,3,4,5,6,7,8,9,10,11,12,13,14,15,16,17,18,19,20,23,24,26,27,28,30,34,37,39$, 46, 48, 49, 50 and 51. Reference strains CCM 6214, serotype HS 23, and CCM 6212, serotype HS9, were used in order to check the results of agglutination.

\section{PCR method}

Results of standard cultivation and typing were verified using the PCR method. This method was also employed when the results of standard typing were ambiguous. A total number of 50 strains of various serotypes was examined by the PCR method. 
The DNA was obtained by boiling $50 \mu \mathrm{l}$ of the bacterial culture suspension for 15 minutes and then subjecting the sample to centrifugation at $10000 \mathrm{~g}$ for 5 minutes. For the purpose of differentiating $C$. lari, 3 primers were used (Promega which define fla $A$ and fla $B$ with the following sequence: CF 03:5'GCTCAAAGTGGTTCTTATGCNATGG-3'; CF02:5'-AAGCAAGAAGTGTTCCAAGTTT-3'a CF 04:5'GCTGCGGAGTTCATTCTAAGACC-3' (Wegmüller et al. 1993). Optimum concentrations for the PCR (20 $\mu \mathrm{l}$ of the final volume) were: $4 \mathrm{mM} \mathrm{MgCl}_{2}$ (Promega), $0.2 \mu \mathrm{M}$ of primers, $200 \mu \mathrm{M}$ (of each) of nucleotides (dATP, dCTP, dGTP and dTTP (Promega) and 2 U Taq DNA polymerase (Promega). The PCR proper took place in the thermocycler (Techne) under the temperature regime: $94^{\circ} \mathrm{C}$ for $4 \mathrm{~min}, 95^{\circ} \mathrm{C}$ for $5 \mathrm{~s}$ ( 40 cycles), $53{ }^{\circ} \mathrm{C}$ for 3 $\min , 72{ }^{\circ} \mathrm{C}$ for $40 \mathrm{~s}$ and $72{ }^{\circ} \mathrm{C}$ for $5 \mathrm{~min}$. The final product $(5 \mu \mathrm{l})$ was analysed using agar gel electrophoresis $(0.8$ $\%$ agarose Sigma Chemical Co. Ltd $)$ and made visible by ethidium bromide $\left(0.5 \mu \mathrm{g} \cdot \mathrm{ml}^{-1}\right.$, Sigma Chemical Co. Ltd $)$ staining and UV transillumination at the wavelength of $312 \mathrm{~nm}$ to check for successful amplification. The size of obtained products was determined by the PCR marker (Promega).

\section{Results}

In all, 178 strains of Campylobacter spp. were isolated. Using standard tests, isolates from human patients were classified as Campylobacter jejuni (98\% $\% 108$ strains) and C. coli ( 2 strains $=2 \%)$. Approximately one half of isolated strains originated in patients of up to 5 years of age. About $30 \%$ of isolations of Campylobacter jejuni were isolated from children and juveniles of up to 18 years of age and the rest of isolated strains originated in adult patients belonging, however, to younger or middle age categories.

Campylobacter spp. strains (20) obtained from slaughtered pigs were identified using the standard tests as C. coli (45\%=9 strains) and C. jejuni $(40 \%=8$ strains) and 3 strains were not identified by the standard tests.

Campylobacter spp. strains (48) isolated from slaughtered poultry were identified as C. jejuni $(89 \%=$ 42 strains) and 6 strains were not identified.

In 130 Campylobacter jejuni strains isolated from poultry and human patients, serotyping using the Penner's scheme was performed. The method used was sufficient for identification of $80 \%$ of strains. The other $20 \%$ of strains could not be serotyped using this method and selected sera. There were found differences in the results of serotyping human and poultry strains (Tab 1). In human C. jejuni strains there were identified 10 different serotypes having different prevalence. Serotypes 4, 1 and 9 (32\%, 23\% and $15 \%$, respectively) were predominating in the human population, followed by serotypes

Table 1

Results of serotyping heat-stable (HS) antigens of Campylobacter jejuni strains of poultry and human origin

\begin{tabular}{|c|c|c|}
\hline Origin of strains & Serotypes (HS) & Number of strains (\%) \\
\hline \multirow[t]{13}{*}{ Human strains } & 4 & $28 \quad(32)$ \\
\hline & 1 & $19 \quad(23)$ \\
\hline & 9 & $13 \quad(15)$ \\
\hline & 10 & $8 \quad(8)$ \\
\hline & 2 & $4 \quad(5)$ \\
\hline & 23 & $2 \quad(3)$ \\
\hline & 50 & $1 \quad(1)$ \\
\hline & 6 & $1 \quad(1)$ \\
\hline & 11 & $1 \quad(1)$ \\
\hline & 13 & $1 \quad(1)$ \\
\hline & 4,13 & $1 \quad(1)$ \\
\hline & 13,50 & $(1)$ \\
\hline & $\mathrm{NT}^{*}$ & $8 \quad(8)$ \\
\hline Total & & $88(100)$ \\
\hline \multirow[t]{9}{*}{ Poultry strains } & 4 & $16 \quad(37)$ \\
\hline & 23 & $7 \quad(17)$ \\
\hline & 1 & $6 \quad(15)$ \\
\hline & 34 & $4 \quad(10)$ \\
\hline & 44 & $2 \quad(6)$ \\
\hline & 10 & $1 \quad(2)$ \\
\hline & 47 & $(2)$ \\
\hline & 1,44 & $1 \quad(2)$ \\
\hline & $\mathrm{NT}^{*}$ & $4 \quad(9)$ \\
\hline Total & & 42 (100) \\
\hline
\end{tabular}

*NT - strains which could not be serotyped by the HS antisera used 
10,2 and $23(8 \%, 5 \%$ and $3 \%$, respectively), and one strain at a time we gained of serotypes 50 ,

6,11 and 13 .

In poultry strains, 7 serotypes with somewhat different frequency were identified. The serotype 4 , which was found in $37 \%$ of examined isolates, was prevailing like among the human strains. The serotype 23 was the second most frequent one and it was followed by the serotype 1 (17\% and 15\%, respectively). In 10\% we found the serotype 34 and the other identified serotypes (44, 10 and 47) were found only in 1 or 2 of tested strains. In 3 strains we identified more than 1 serotype; i.e., 1, 44, 13, 50 and 4, 13. Comparing the obtained serotypes from human and poultry strains we found only 4 identical ones $(4,1,10,23)$ which, however, belonged to the most prevalent serotypes in both groups of strains. Because of the low number of isolated strains from pigs, these strains were not serotyped. In this paper we compare results of standard isolation and identification of Campylobacter spp. strains with possibilities of using the PCR method. The PCR system uses two primers located at the start (CF 04) of fla B and at the end of fla A (CF 03). The obtained PCR fragments were the size of 340 to $380 \mathrm{bp}$ (Plate I., Fig. 1). The third primer (CF 02) forms a product of the size of 180 to $220 \mathrm{bp}$. The size of isolated fragments may differ within the above-mentioned range between individual strains, because there may be differences in the inter gene sequence of flagellin in individual strains. All the $C$. jejuni and $C$. coli strains form a band the size of 340 to $380 \mathrm{bp}$. There are similar results in $C$. lari strains, but when 3 PCR primers are used in $C$. jejuni and $C$. coli, a smaller fragment CF 03-CF02 (180 to $220 \mathrm{bp}$ ) not found in $C$. lari is formed. In all the strains which were identified using the standard method as $C$. jejuni or $C$. coli, the results were confirmed by the PCR method. Evaluating 9 strains which could not be identified by biochemical tests, 4 isolates were identified as $C$. jejuni/coli by the PCR method.

\section{Discussion}

Serotyping belongs to the most widespread phenotyping methods. The Penner's serotyping scheme uses 62 antisera (HS) at present, and the Lior's system works with 122 antisera (HL) (Asrat et al. 1997). Regarding the high number of antisera it is clear that only a selected group of them is mostly used. That is because there are serotypes which are occurring in most countries with various frequency. Nearly $90 \%$ of isolated serotypes belong to the 20 most prevalent ones (Lastovica et al. 1998). In Europe there are frequently occurring HS serotypes 1, 2, 4, 6, 8, 21, 26, 31, 44 and HL serotypes 1, 2, 6, 9, 11. Sjörgen et al. (1989) studied the prevalence of individual serotypes during a given time interval in Sweden. They found that $76 \%$ of serotypes are in agreement with results obtained five years ago. Serotypes HS 2 (33\% of studied strains) and HL 4 (42\% of strains) were most prevalent. There were, however, differences in serotypes from persons contracting the disease abroad and in their home country. Among strains contracted abroad, there were serotypes previously occurring only sporadically or not at all in Sweden.

Serotyping C. jejuni/coli strains from human patients in Etiopia, Asrat et al. (1997), in accordance with other countries of the world, found the highest frequency of occurrence of serotypes HS 1, 3, 8, 26 and 34. These authors, however, found that about a quarter of strains was positive for more than 1 serotype. This fact is also known from other papers, but such strains are found in much more lower numbers. Some authors explain this fact by the frequent occurrence of $C$. jejuni/coli strains in children in developing countries and subsequent difficulties in gaining pure cultures of only one strain. Poultry, hosting very frequently $C$. jejuni, are considered as one of the main sources of the agent. A great number of papers (Aarts et al. 1995; Annan-Prah et al. 1988; Jacobs-Reitsma et al. 1995) were engaged in studying and comparing serotypes isolated from patients and poultry. Serotypes from poultry only partly agree with isolates 
from human patients. According to the study by Annan-Prah (1988), such serotypes as HS 1, 2, 5, 7, 9 and 22 were most frequently isolated from slaughtered poultry and ill human patients. The most prevalent serotype was HS 2. The serotype HS 8, i.e., the second most frequently found one in human patients, was not isolated from poultry at all. Our results show that serotypes HS 4 and 1 were most frequently occurring in our sample of strains of poultry and human origin. The next frequent serotypes in human patients were HS 9, 10 and 2, while in poultry 23, 34 and 44.The serotype HS 9, the third most prevalent one in human patients, was not isolated from poultry at all, like serotypes HS 2, 6, 11, 13 and 50. On the other hand, there were serotypes HS 44 and 47 in poultry, which were not found in strains from human patients. It is supposed that some frequent serotypes from poultry are less pathogenic for humans and, therefore, occur in the human population only sporadically (Jacobs-Reitsma et al. 1995). Considering the fact that only about one half of human and poultry isolates is identical from the point of view of serotyping, it is probable that there exist also other sources of the disease for humans than poultry, i.e., pigs, water, other domestic animals, etc. According to our results, the PCR method is suitable as a sensitive and specific method for $C$. jejuni and $C$. coli detection. This finding may be significant in studying some epidemics caused by Campylobacter jejuni, when results by standard methods are negative. Foodstuffs do not provide suitable conditions for the survival of campylobacters and the time elapsing after the onset of the disease is usually too long to enable successful isolation of the agent from the suspect vehicle by standard methods. This is why application of the PCR method in justified cases may be of advantage and help in epidemiological investigations (Madden et al. 1998). The other advantage of the PCR method is given by the possibility to prove agents directly from foodstuffs which cuts considerably the time requirements. It is also the sensitivity of the PCR method that is very high. We g müller et al. (1993) mention the possibility to detect 10 to 100 cells directly from water, milk or cheese. The identification of infectious agents directly from foodstuffs is limited by problems connected with foodstuff composition complicating the isolation of the bacterial DNA. Such techniques, nevertheless, are paid great attention and there are already described functional systems for simple matrices. We have to bear in mind that it is not possible to omit standard methods of cultivation necessary for obtaining pure cultures needed for further tests and characteristics. We suppose that the combination of phenotypic and genotypic methods is a suitable way for epidemiological studies of Campylobacter spp. spread in the food chain. The PCR methods may facilitate and make more accurate the results of standard cultivation and, in disputed cases, help to prove the agent not diagnosed by common methods.

\section{Serotypizace a identifikace kmenů Campylobacter jejuni a Campylobacter coli humánního a zvířecího pủvodu použitím metody řetězové polymerázové reakce (PCR)}

V průběhu let 1996-1997 bylo izolováno celkem 178 kmenů Campylobacter sp. od humánních pacientů trpících průjmy a ze střevního obsahu porážených prasat a drůbeže. Izolace a identifikace Campylobacter spp. byla prováděna klasickými testy a současně i metodou polymerázové řetězové reakce (PCR) využívající fla $A$ a fla $B$. Izoláty pocházející od lidských pacientů byly identifikovány klasickými testy a PCR jako Campylobacter jejuni (98 \% - 108 kmenů) a 2 kmeny (2\%) jako C. coli. Kmeny Campylobacter sp. (20) získané z porážených prasat byly konvenčními testy určeny v $45 \%$ (9 kmenů) jako C. coli a v $40 \%$ jako C. jejuni (8 kmenů). Kmeny Campylobacter spp. (48) izolované z poražené drůbeže byly identifikovány jako $C$. jejuni (89 \% - 42 kmenů). Běžnými testy nebylo zařazeno 9 kmenů; použitím metody PCR bylo 6 kmenů identifikováno jako Campylobacter jejuni a C. coli. 
U 130 kmenů Campylobacter jejuni izolovaných z drůbeže a od lidských pacientů byla prováděna serotypizace pomocí 34 antisér Pennerova serotypizačního schématu. Použitá metoda byla vyhovující pro identifikaci téměř $80 \%$ kmenů $C$. jejuni. U lidských kmenů $C$. jejuni jsme zjistili 10 různých serotypů. Dominantními v humánní populaci byly serotypy HS 4 , 1, a $9(32 \%, 23 \%$ a $15 \%)$, následovaly serotypy HS 10, 2 a 23 (8\%, 5\% a $3 \%)$. U zviŕecích kmenů bylo určeno 7 serotypů . Podobně jako u lidských kmenů prevevažoval serotyp HS 4, který jsme zjistili u 37 \% vyšetřovaných izolátů. Druhý nejčastějǔ́i serotyp byl 23 a následoval serotyp $1(17 \%$ a $15 \%)$. Při porovnávání získaných serotypů byly u humánních a lidských kmenů totožné pouze 4 serotypy (HS 4,1,10,23), které však patřily mezi nejčastěji zastoupené u obou skupin kmenů.

Metody PCR a serotypizace mohou usnadnit a upřesnit výsledky klasické kultivace a v epidemiologicky závažných př́ipadech mohou pomoci objasnit cestu přenosu.

\section{References}

AARTS, H. J. M., VAN LITH, L. A. J. T., JACOBS-REITSMA, W. F. 1995: Discrepancy between Penner serotyping and polymerase chain reaction fingerprinting of Campylobacter isolated from poultry and other animal sources. Lett. Appl. Microbiol. 20: 371-374

ANNAN-PRAH, A., JANC, M. 1988: Chicken-to-human infection with Campylobacter jejuni and Campylobacter coli: biotype and serotype correlation. J. Food Protect. 51: 562-564

ASRAT, D. A., HATHAWAY, A., SJÖRGEN, E., EKWALL, E., KAIJSER, B. 1997: The serotype distribution of Campylobacter jejuni and C. coli isolated from patients with diarrhoea and controls at Tikur Anbassa Hospital, Addis Abeba, Ethiopia. Epidemiol. Infect. 118: 91-95

BOVILL, R. A., MACKEY, B. M. 1997: Resuscitation of "non-culturable" cells from aged cultures of Campylobacter jejuni. Microbiology 143: 1575-1581

ČSN ISO normy 10272 "Mikrobiologie poživatin a krmiv - Horizontální metoda průkazu termotolerantních druhů rodu Campylobacter"

JACOBS-REITSMA, W. F., MAAS, H. M. E., JANSEN,W. H. 1995: Penner serotyping of Campylobacter isolates from poultry, with absorbed pooled antisera. J. Appl. Bacteriol. 79: 286-291

LASTOVICA, J., NEWELL, D. G., LASTOVICA, E. E. 1998: Campylobacter, Helicobacter and Related Organisms. Proceedings of the $9^{\text {th }}$ International Workshop, $627 \mathrm{p}$.

MADDEN, R H., MORAN, L., SCATES, P. 1998: Frequency of occurrence of Campylobacter spp. in red meats and poultry in Northern Ireland and their subsequent subtyping using polymerase chain reaction-restriction fragment length polymorphism and the random amplified polymorphic DNA method. J. Appl. Microbiol. 84: 703-708

McDOUGALD, D., RICE, S. A., WEICHART, D., KJELLEBERG, S. 1998: Nonculturability: adaptation or debilitation? FEMS Microbiology Ecology 25: 1- 9

PENNER, J. L., HENNESSY, J. N. 1980: Passive hemagglutination technique for serotyping Campylobacter fetus subsp. jejuni on the basis of soluble heat-stable antigens. J. Clin. Microbiol. 12: 732-737

SAHA, S. K., SAHA, S., SANYAL, S.C. 1991: Recovery of injured Campylobacter jejuni cells after animal passage. Appl. Environ. Microbiol. 57: 3388-3389

SALEHA, A. A., MEAD, G. C., IBRAHIM, A. L. 1998: Campylobacter jejuni in poultry production and processing in relation to public health. Worldęs Poultry Sci. J. 54: 49-58

SJÖRGEN, E., ALESTIG, K., KAIJSER, B. 1989: Campylobacter strains from Swedish patients with diarrhoea. APMIS 97: 221-226

STEINHAUSEROVÁ, I. 1998: Campylobacter spp. v prostředí a v potravinách živočišného původu. Ed. LAST, Brno, $110 \mathrm{p}$.

WEGMÜLLER, B., LUTHY, J., CANDRIAN, U. 1993: Direct polymerase chain detection of Campylobacter jejuni and Campylobacter coli in raw milk and dairy products. Appl. Environ. Microbiol. 59: 2161-2165 
Plate I

I. Steinhauserová, K. Fojtíková: Serotyping... pp. 149-154

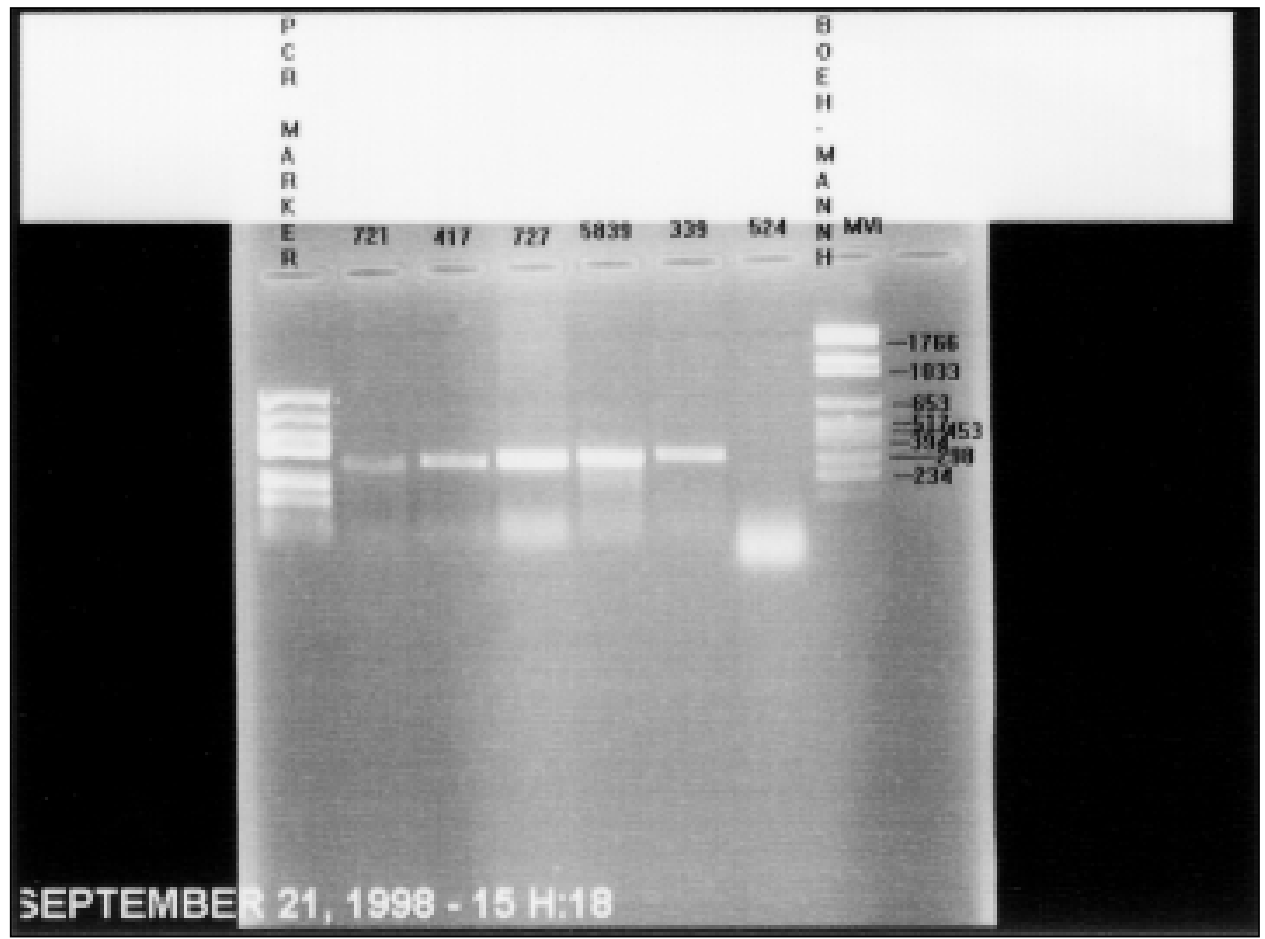

Fig. 1. PCR analysis of representative $C$. jenuni strains isolated from chickens. 1. PCR marker (Top Bio), 2.-5 C. jenuni strains from chickens, 6. C. fetus, 7. PCR marker MVI (Boehringer) 